\title{
Population dynamics of freshwater snails (Mollusca: Gastropoda) at Qena Governorate, Upper Egypt
}

\author{
Mohamed A. Hussein ${ }^{1}$, Ahmad H. Obuid-Allah ${ }^{1}$, Amal A. Mahmoud ${ }^{2}$ and \\ Heba M. Fangary ${ }^{2}$ \\ 1-Department of Zoology, Faculty of Science, Assiut University, Egypt \\ 2 - Department of Zoology, Faculty of Science, South Valley University, Egypt
}

\section{ABSTRACT}

Monthly and seasonal fluctuations in densities of freshwater snails were recorded in six different sites at Qena Governorate during the period of March 2009 February 2010. The study revealed the occurrence of 13 species of freshwater snails belonging to 9 families of class Gastropoda. The snail species and their total catch were: Cleopatra bulimoides (1704 specimens), Lanistes carinatus (1468 specimens), Melanoides tuberculata (1036 specimens), Gabbiella senaariensis (731 specimens) Theodoxus niloticus (670 specimens), Bellamya unicolor (588 specimens), Physa acuta (213 specimens), Lymnaea natalensis (145 specimens), Succinea cleopatra (85 specimens), Bulinus truncatus (73 specimens), Biomphalaria alexandrina (41 specimens), Gyraulus ehrenbergi (12 specimens) and Helisoma duryi (2 specimens) in a descending order. The densities of the recorded snails varied seasonally and the general seasonal peak was recorded during Autumn while the lowest density observed during Winter. Ecological factors which may influence the distribution of the recorded snails were also determined (water temperature, $\mathrm{pH}$, dissolved oxygen conductivity, total hardness, total dissolved salts, water depth and percentage of macrophytes).

Keywords: Population dynamics, snails ,Qena Governorate, Egypt

\section{INTRODUCTION}

Freshwater molluscs have been known to play significant roles in the public and veterinary health and thus need to be scientifically exploring more extensively (Supian \& Ikhwanuddin, 2002). About 100 species of freshwater gastropods are reported to act as intermediate hosts for the diagnostic trematode parasites and among Prosobranchs, members of the family Pilidae and Thiaridae were recorded to harbor larval trematodes (Subba-Rao, 1993). Several factors are considered as affecting the ecology of snails and other intermediate hosts of diseases, hence their focal and seasonal distributions. These include physical factors such as water current, temperature, turbidity, transparency and distribution of suspended solids, chemical factors such as ion concentration and dissolved gases in water as well as biological factors such as availability of food, competition and predator-prey interactions (Williams, 1970; Ofoezie, 1999). Besides, the aquatic macrophytes have been shown to play vital roles in the distribution of snails in different parts of Africa (Ofoezie, 1999). However, the importance of different ecological factors vary significantly from one ecological zone to the other and even from one water body to the other, suggesting local investigations to identify important factors in each zone or water bodies (Dazo et al., 1966; Klumpp \& Chu, 1977; Imevbore et al., 1988; Ofoezie, 1999). Many studies concerned with the ecology and population dynamics of the 
group of gastropods which play an important role in transmitting diseases to man and his livestock have been conducted by Abd El-Malek (1958); Dazo et al. (1966); Barbosa \& Barbosa1994); Utzinger et al. (1997); Kloos et al. (2001); Karimi et al. (2004); Cañete et al. (2004) Kazibwe et al. 2006 and Mostafa, 2009). These studies have led to general opinion; that the development of an effective strategy of integrated control requires the study of population dynamics of the intermediate hosts and its relation to environmental factors. Population dynamics of these animals depend on the physical geography of a given region, also land contours, soil composition, hydrography and climate all have effect on snail population dynamics (El-Khayat et al., 2011).

This study is intended to produce data on the distribution, monthly and seasonal variations in densities of gastropod molluscs at Qena Governorate with emphasis on environmental factors affecting them.

\section{MATERIALS AND METHODS}

Sites of investigation: The collecting of snails was carried out in six sites at Qena Governorate, three sites situated on an irrigation canal (El-Kelabia) (sites I, II and III), while the other three sites found on the River Nile (sites (III, IV and VI). These sites are: Ezbt El-Bosa (Naj Hamadi) (I) $\left(26^{\circ} 06^{-} \mathrm{N} / 32^{\circ} 20^{-} \mathrm{E}\right)$; Faw Bahary (II) $\left(26^{\circ} 06^{-}\right.$

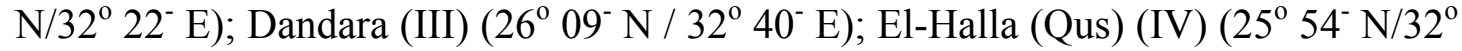
$\left.46^{-} \mathrm{E}\right)$; El-Madamod (Luxor) (V) $\left(25^{\circ} 44^{-} \mathrm{N} / 32^{\circ} 42^{-} \mathrm{E}\right)$ and El-Bogdade (Luxor) (VI) $\left(25^{\circ} 39^{-} \mathrm{N} / 32^{\circ} 36^{-} \mathrm{E}\right)$, (Fig. 1).

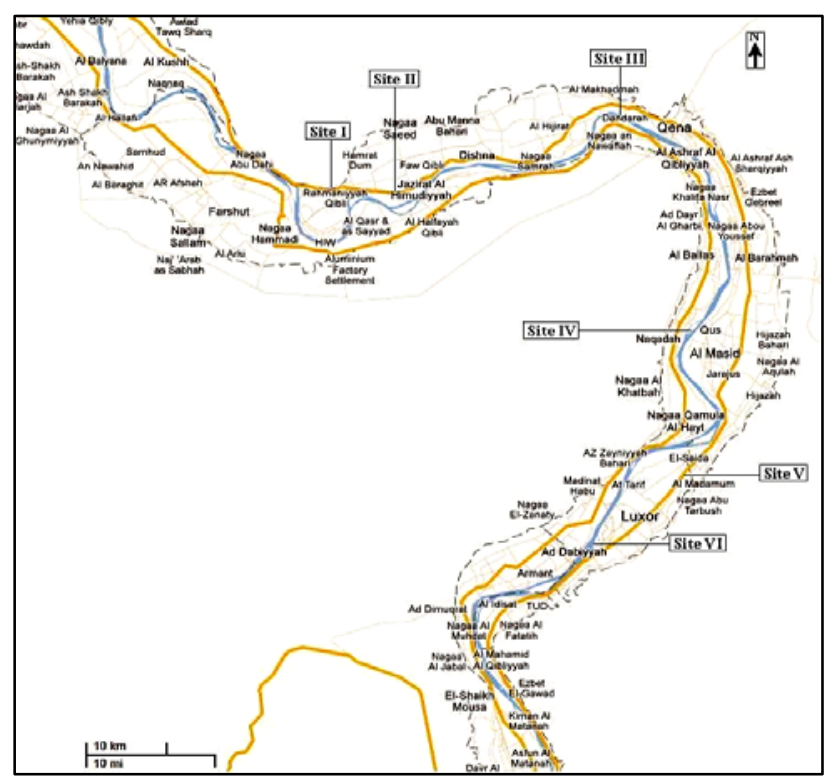

Fig.1: A map showing the sites of investigation

Sampling of snails: Monthly samples of freshwater snails were collected from the six sites during a period of one year (from March, 2009 till February, 2010). Sampling was carried out along the shoreline of each site and always by the same collector. Snails were collected by passing a dip net $(30 \mathrm{~cm} \times 40 \mathrm{~cm})$ five times through the upper surface of sediment, water and vegetations on a depth of $20 \mathrm{~cm}$ (a column of water as parallel rectangles and its base is the rectangular net). The snails attached to the macrophytes were separated and all collected snails were kept in pre-labeled plastic containers. In the laboratory, the snails were counted and identified according 
to Brown (1994) and Ibrahim et al. (1999) keys' then preserved in 70\% ethyl alcohol. The density of each species was calculated as the number of specimens present in the five samples at the volume of water column as parallel rectangles, which was calculated as $120000 \mathrm{~cm}^{3}$.

Ecological factors: Water temperature, $\mathrm{pH}$, dissolved oxygen, conductivity and total dissolved salts were measured by digital probe apparatuses. Calcium and magnesium concentrations were evaluated by the Atomic Absorption Spectrophotometer and total hardness was calculated according to Vermani \& Narula, 1995. Water depth (cm) was measured by a wooden meter. The percentage of macrophytes was determined according to Owojori et al. (2006) by simple estimation of the proportion of a site covered by floating and anchored plants and scored as 1 for $<10 \%, 2$ for $10-30 \%, 3$ for $31-50 \%, 4$ for $51-70 \%$ and 5 for $>70 \%$.

Statistical analysis: Analysis of Variance on SPSS software package (version 16) (SYSTAT statistical program) was used to test the present data. Perrson correlation coefficients were calculated between the densities of the recorded species and environmental factors (all these variables were inserted in the analysis box of bivariate correlation).

\section{RESULTS AND DISCUSSION}

A total of 13 snail species belonging to 9 families under class Gastropoda were collected from the sites of investigation during the study period. These species are: Lanistes carinatus (Olivier, 1804) (Ampullaiidae), Bellamya unicolor (Olivier, 1804) (Viviparidae), Cleopatra bulimoides (Olivier, 1804), Melanoides tuberculata (Müller, 1774) (Thiaridae), Theodoxus niloticus (Reeve, 1856) (Niritidae), Gabbiella senaariensis (küster, 1852) (Bithyniidae), Lymnaea natalensis (Krauss, 1848)) (Lymnaeidae), Succinea cleopatra (Pallary, 1909) (Succineidae), Physa acuta (Draparnaud, 1805) (Physidae), Bulinus truncatus (Audouin, 1827), Biomphalaria alexandrina (Ehrenberg, 1831), Gyraulus ehrenbergi (Beck, 1837) and Helisoma duryi (Wetherby, 1879) (Planorbidae).

As shown in Table (1), the total number of the collected snails was 6768 specimens, from which 2230, 225, 598, 1507, 959 and 1249 individuals were recorded at sites I, II, III, IV, V and VI respectively. By regarding these results, one can conclude that site I and site IV were rich in snails. It was observed that site I characterized by muddy substrate with organic matter; the shore profile is gradually sloping to the bottom; slow water current and rich in different types of water weeds. Site IV had a clay-sandy substratum with decaying matter and a lot of vegetations.

Table 1: The total relative densities of the snail species recorded from the studied sites during the period of investigation.

\begin{tabular}{|c|c|c|c|c|c|c|c|c|c|c|c|c|c|c|}
\hline Site & L.c. & B. $u$. & C. b. & M.t. & T. n. & G. s. & L. $n$. & S. c. & P. $a$. & B. $t$. & B. $a$. & G. $e$. & H.d. & Total \\
\hline I & 823 & 386 & 141 & 116 & 0 & 703 & 3 & 0 & 55 & 3 & 0 & 0 & 0 & 2230 \\
\hline II & 35 & 58 & 0 & 45 & 0 & 2 & 64 & 0 & 13 & 5 & 0 & 3 & 0 & 225 \\
\hline III & 152 & 26 & 290 & 26 & 3 & 0 & 22 & 48 & 19 & 9 & 3 & 0 & 0 & 598 \\
\hline IV & 40 & 90 & 505 & 163 & 528 & 21 & 19 & 27 & 82 & 14 & 15 & 3 & 0 & 1507 \\
\hline $\mathbf{V}$ & 5 & 16 & 277 & 644 & 13 & 0 & 0 & 0 & 1 & 3 & 0 & 0 & 0 & 959 \\
\hline VI & 413 & 12 & 491 & 42 & 126 & 5 & 37 & 10 & 43 & 39 & 23 & 6 & 2 & 1249 \\
\hline Total & 1468 & 588 & 1704 & 1036 & 670 & 731 & 145 & 85 & 213 & 73 & 41 & 12 & 2 & 6768 \\
\hline
\end{tabular}

L. c.: Lanistes carinatus; B. u.: Bellamya unicolor; C. b.: Cleopatra bulimoides; M. t.: Melanoides tuberculata;

T. n.: Theodoxus niloticus; G. s.: Gabbiella senaariensis; L. n.: Lymnaea natalensis; S. c.: Succinea cleopatra;

P. a.: Physa acuta; B. t.: Bulinus truncatus; B. a.: Biomphalaria alexandrina; G. e.: Gyraulus ehrenbergi;

H. d.: Helisoma duryi

These results are in accordance with Lacoursiere et al. (1975) and Vincent et al. (1982); they suggested that gastropod variability may be explained by abiotic factors (depth, current and sediment). Also Strzelec \& Królczyk (2004) indicated that 
many gastropod species are tolerant to most physicochemical water parameters and their occurrence is affected by the quality of bottom sediments and vegetation abundance and reported that the most suitable substrate for snails in rivers is a sandy bottom covered with thin layer of organic silt.

The values range of physico-chemical properties of water in the sampling stations are shown in table (2), and it was observed that the differences between sites were highly significant except for water temperature

Table 2: The values range of physico-chemical parameters recorded in water at the investigated sites

\begin{tabular}{|c|c|c|c|c|c|c|c|c|c|c|}
\hline Site & $\begin{array}{c}\mathbf{W} . \mathbf{T} . \\
{ }^{\circ} \mathrm{C}\end{array}$ & $\mathbf{p H}$ & $\begin{array}{c}\mathbf{D O 2} \\
\mathrm{ppm}\end{array}$ & $\begin{array}{c}\mathbf{C o n d} \\
\mathrm{mS}\end{array}$ & $\begin{array}{c}\text { T. H. } \\
\mathrm{Mg} / \mathrm{L}\end{array}$ & $\begin{array}{c}\text { T.D.S. } \\
\mathrm{Mg} / \mathrm{L}\end{array}$ & $\begin{array}{c}\mathbf{C a}^{2+} \\
\mathrm{Mg} / \mathrm{L}\end{array}$ & $\begin{array}{c}\text { W. D. } \\
\mathrm{Cm}\end{array}$ & $\begin{array}{c}\text { Flo. P. } \\
\%\end{array}$ & $\begin{array}{c}\text { An. P. } \\
\%\end{array}$ \\
\hline I & $16-28.7$ & $6.8-7.8$ & $4.8-9.3$ & $0.26-0.71$ & $91-279.8$ & $155-430$ & $16.3-64.1$ & $55-100$ & - & $30-90$ \\
\hline II & $16.5-28.2$ & $6.4-7.9$ & $4.2-8.4$ & $0.26-0.47$ & $79.9-203.5$ & $155-445$ & $24.1-44.1$ & $77-130$ & - & $10-70$ \\
\hline III & $18.4-27$ & $6.9-7.8$ & $6.4-9.5$ & $0.28-0.93$ & $103-437.8$ & $168.1-638$ & $26.6-77.5$ & $42-70$ & $<10-90$ & $10-70$ \\
\hline IV & $18.7-27.3$ & $6.95-8.2$ & $6.4-8.9$ & $0.25-0.51$ & $72.2-180.9$ & $147-304$ & $16.03-48.1$ & $54-89$ & - & $30-80$ \\
\hline V & $16.5-26.6$ & $7.3-8.3$ & $6.3-12.5$ & $0.24-0.59$ & $92.4-168.8$ & $145-243$ & $29.5-56.1$ & $72-160$ & $<10-70$ & $10-80$ \\
\hline VI & $17-25.3$ & $7.24-7.95$ & $6.8-9.5$ & $0.24-0.67$ & $93.1-255.1$ & $146-402$ & $14.6-44.1$ & $45-85$ & $<10-70$ & $10-80$ \\
\hline
\end{tabular}

(W.T.: water temperature, DO2: dissolved oxygen, Cond.: conductivity, T. H.: total hardness, T. D. S.: total dissolved salts, W. D. water depth, Flo. P.: floating plants, An. P: anchored plants)

According to the numbers of collected snails, the species were arranged in a descending order as: Cleopatra bulimoides (1704 specimens), Lanistes carinatus (1468 specimens), Melanoides tuberculata (1036 specimens), Gabbiella senaariensis (731 specimens), Theodoxus niloticus (670 specimens), Bellamya unicolor (588 specimens), Physa acuta (213 specimens), Lymnaea natalensis (145 specimens), Succinea cleopatra (85 specimens), Bulinus truncatus (73 specimens), Biomphalaria alexandrina (41 specimens), Gyraulus ehrenbergi (12 specimens) and Helisoma duryi (2 specimens) table(1).

Seasonally, the total catch of snails showed its highest value during Autumn (representing 38.8\%), followed by Summer (24.8\%), then Spring (18.6\%), whereas the least catch was recorded in Winter (17.8\%) Fig. (2). The present result agrees with Karimi et al. (2004) where they found that late Summer and Autumn had the optimal temperature required for breeding and reproduction of snails, and partially agrees with El-Kady et al. (2000); they stated that April, May and June showed the highest number of snails in Sinai Peninsula, while the lowest number was recorded during January and February.

\section{- Monthly and seasonal variations of the recorded snail species}

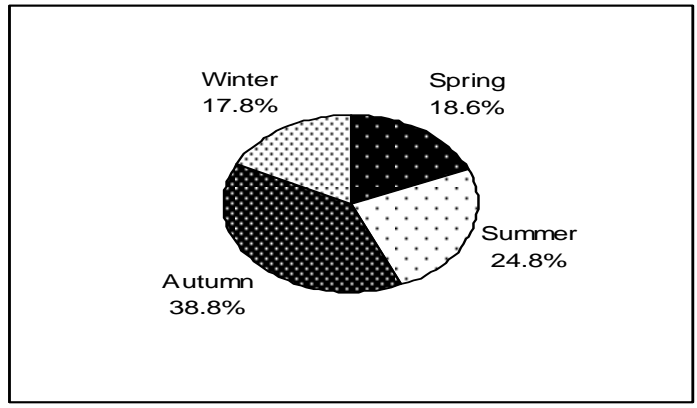

Fig. 2: The seasonal percentages of the snail species collected from the studied sites.

Also, partially agrees with Zaki (2008) who reported that the snail population was high in Autumn and low in Summer and Spring in Abis district, Alexandria. In 
the contrary, Dazo et al. (1966) indicated that snails were abundant in summer, decline during late summer and undergo a lesser increase during Autumn, and Diab (1993) reported that the snail abundance was high in Spring and low in Summer in Beheira Province.

Figure (3) showed the monthly variations in the density of each snail species collected from the studied sites (except G. ehrenbergi and $H$. duryi due to the few numbers recorded).
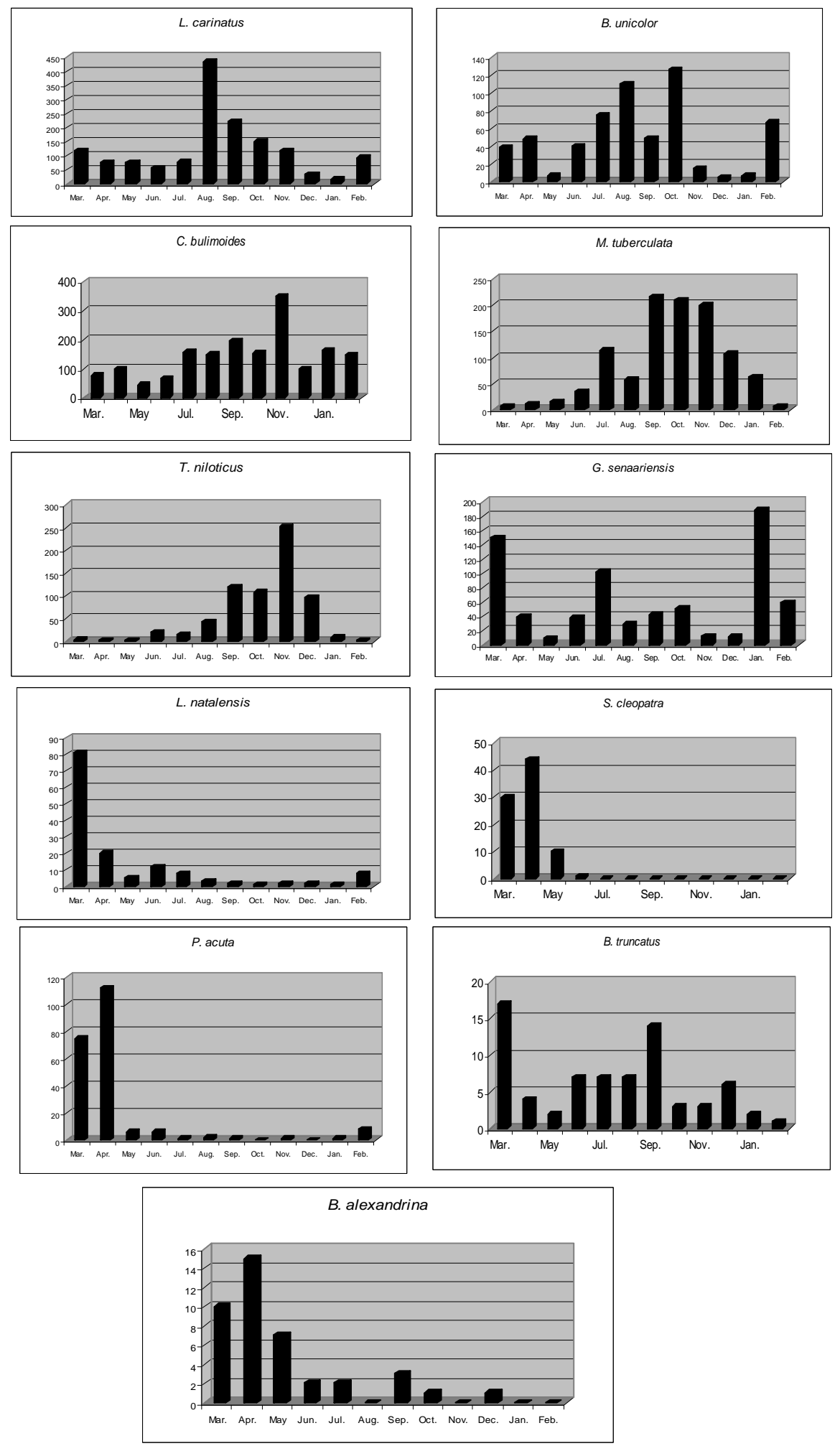

Fig. 3: The monthly variations of the snail species densities collected from the investigated sites. 
L. carinatus showed the highest peak in August and B. unicolor showed a peak in August/October, this agrees with Heikal \& El-Sokkary (1986) in Edfina area. C. bulimoides and T. niloticus showed their peaks in November and M. tuberculata showed September-November peak, this agrees with Diab (1993) and Zaki (2008) in Beheira Province and Abis district respectively. G. senaariensis showed January peak, this result disagrees with El-Kady et al. (2000) where they found the highest number of this species in April. L. natalensis, S. cleopatra, P. acuta and B. alexandrina showed March-May peak, while B. truncatus showed two peaks in March and September, this is in accordance with Diab (1993), El-Kady et al. (2000) and Zaki (2008).

\section{- Size structure of the recorded species}

L. carinatus showed a maximum reproduction during Summer and the most important cohort of small-sized individuals appeared in July 2009. This result is in accordance with that of Aboul-Ela \& Beddiny (1970) where they stated that the egg laying of this species, at Cairo, mostly occurred during the warm season (from May to August) and breeding ceases in the winter.

B. unicolor showed a high breeding during Summer and the small-sized cohort appeared in June 2009. This result agrees with Brown (1994) who stated that the reproduction took place during the warm season in Tchad Lake and the high birth rate was found from May to June.

C. bulimoides was collected in large numbers and the percentages of smallsized individuals were low during all seasons and the highest one was in Autumn and the percentages of adult snails were high during the four seasons and the highest was during Spring. This means that there was no great fluctuation in the population of this species. This result is in accordance with Zaki (2008) who found the changes in size of this species at Alexandria with little differences between months and the smallest size obtained was in Autumn. Pointier et al. (1993) reported that snails which remained at high densities showed few fluctuations in their populations. Also Brown (1994) recorded the effect of crowding which inhibit the growth and reproduction in crowded cultures of snails by shortage the food of high quality.

M. tuberculata showed a maximum cohort of small-sized individuals in October 2009. Pointier et al. (1993) recorded a maximum reproduction of this species in France between June and November and the most important cohort of young snails appeared in June and this species grow slowly and has a long life span.

T. niloticus showed the highest number of small-sized individuals in September. This agrees with Zaki (2008).

The highest number of small-sized individuals of $G$. senaariensis was recorded during Winter. Dussart (1979) suggested that the snail Bithynia tentaculata showed a maximum production of young throughout Autumn and mid-Winter in England and the young snails grow slowly during Winter and Spring.

L. natalensis showed the maximum number of small-sized specimens during Spring. Karimi et al. (2004) showed that young snails were observed in Autumn and early Winter and old snails were collected during Summer in Iran. Zaki (2008) collected the maximum number of small specimens of this species in April.

S. cleopatra was recorded during Spring only and the highest percentage of small-sized individuals was observed in May. Ramzy (2009) recorded this species (as the land snail Oxyloma elegans) in Assiut Governorate all the year of collection and young snails were found during the period of investigation but in low percentages and they flourish only in Spring. 
P. acuta showed a maximum percentage of small snails in April 2009. Zaki (2008) recorded the smallest sizes of this snail in April and February.

B. truncatus showed nearly stable number of small-sized individuals during Spring, Summer and Autumn seasons. Dazo et al. (1966) reported that although eggs may be laid in all months, peak egg production occurs from February to April, possibly stimulated by increasing temperature and/or heavy rainfall and the second peak of oviposition in the Autumn season. Demian \& Kamel (1972) pointed out that a third Winter generation is recognizable.

For B. alexandrina, the small-sized snails reached their highest number in April. This species seems to be sensitive to high temperature, as peak egg production occurred between February and April and could be stimulated by low mid-Winter temperature in December to February (Dazo et al., 1966).

\section{- Relationship between the environmental factors and the snail species}

From table (3), there was a positive correlation between water temperature and L. carinatus and B. unicolor. Appleton's review (1978) suggested that water temperature is the most important abiotic factor in lentic environments, whereas in lotic environments current velocity is the key factor. Cañete et al. (2004) reported that temperature plays an important role in Lymnaea sp. abundance. Kazibwe et al. (2006) also observed a positive correlation between Biomphalaria sudanica abundance and water temperature.

The $\mathrm{pH}$ was positively correlated with $C$. bulimoides, $M$. tuberculata and $T$. niloticus, while negatively correlated with $L$. carinatus and $B$. unicolor. This agrees with Owojori et al. (2006) where they reported that Potadoma freethi was correlated positively with $\mathrm{pH}$ ( $\mathrm{pH}$ range 6.9-7.5), and Kazibwe et al. (2006) observed that Biomphalaria sudanica abundance was negatively correlated with $\mathrm{pH}$. In the contrary, Abd El-Malek (1958); Ofoezie (1999) and Cañete et al. (2004) showed that $\mathrm{pH}$ is rarely a factor limiting the distribution of the snails.

$L$. carinatus and $B$. unicolor were negatively correlated with the dissolved oxygen, while $C$. bulimoides and $B$. alexandrina were positively correlated. This result supports the view of Ofoezie (1999) who stated that pulmonate snail species increased with increasing dissolved oxygen, while density of prosobranch snails decreased. Abd El-Malek (1958) reported that oxygen content of the water is very important in conditioning the habitat of Bilharzia vector snails. Maqbool et al. (2003) and Karimi (2003) also observed that Lymnaea species were seen floating in the surface because they needed a high rate of oxygen consumption.

A negative correlation was recorded between the total hardness and $B$. alexandrina. Abd El-Malek (1958) observed that Bilharziasis vectors were tolerant of a wide range of hardness and waters of very low hardness showed reduction in individual number and shells become relatively thin. Cañete et al. (2004) indicated that total hardness seemed to play some important role in Lymnaea abundance.

Calcium concentration was negatively correlated with $B$. unicolor, $S$. Cleopatra, P. acuta and B. alexandrina(decreased with increasing Calcium)Several authors showed that calcium concentration is an important factor in controlling the abundance and distribution of molluses in freshwater (Boycott, 1936; Macan, 1950; Mckillop \& Harrison, 1972; Dussart, 1976, 1979; Mckillop, 1985 and Supian \& Ikhwanuddin, 2002).

A negative correlation occurred between water depth and C. bulimoides, $T$. niloticus, S. cleopatra and B. truncatus. El-Kady et al. (2000) recorded that the most effective ecological factors acting upon snail population density in irrigation channels maybe the water depth, aquatic weeds and water temperature. 
Table 3: Correlation coefficient for association between different species with ecological factors during the period of investigation

\begin{tabular}{|c|c|c|c|c|c|c|c|c|c|c|c|}
\hline & & $\begin{array}{l}\text { Water } \\
\text { temp. }\end{array}$ & PH & DO2 & Cond. & $\begin{array}{c}\text { Total } \\
\text { H. }\end{array}$ & TDS & $\mathrm{Ca}^{2+}$ & $\begin{array}{c}\text { W. } \\
\text { depth }\end{array}$ & Flo. P. & $\begin{array}{c}\text { Anch. } \\
\text { p. }\end{array}$ \\
\hline $\begin{array}{c}\text { L. } \\
\text { Carinatus }\end{array}$ & $\begin{array}{c}\mathrm{R} \\
\text { Sig. }\end{array}$ & $\begin{array}{l}0.190 \\
* *\end{array}$ & $\begin{array}{c}-0.199 \\
* *\end{array}$ & $\begin{array}{c}-0.256 \\
* *\end{array}$ & $\begin{array}{c}-0.002 \\
\text { NS }\end{array}$ & $\begin{array}{c}-0.040 \\
\text { NS }\end{array}$ & $\begin{array}{c}-0.005 \\
\text { NS }\end{array}$ & $\begin{array}{c}-0.072 \\
\text { NS }\end{array}$ & $\begin{array}{c}-0.044 \\
\text { NS }\end{array}$ & $\begin{array}{c}-0.081 \\
\text { NS }\end{array}$ & $\begin{array}{c}-0.056 \\
\text { NS }\end{array}$ \\
\hline $\begin{array}{c}\text { B. } \\
\text { Unicolor }\end{array}$ & $\begin{array}{c}\mathrm{R} \\
\text { Sig. }\end{array}$ & $\begin{array}{c}0.184 \\
* *\end{array}$ & $\begin{array}{c}-0.263 \\
* *\end{array}$ & $\begin{array}{c}-0.306 \\
* *\end{array}$ & $\begin{array}{c}-0.084 \\
\text { NS }\end{array}$ & $\begin{array}{c}-0.087 \\
\text { NS }\end{array}$ & $\begin{array}{c}-0.071 \\
\text { NS }\end{array}$ & $\begin{array}{c}-0.134 \\
*\end{array}$ & $\begin{array}{c}0.030 \\
\text { NS }\end{array}$ & $\begin{array}{c}-0.215 \\
* *\end{array}$ & $\begin{array}{c}-0.017 \\
\text { NS }\end{array}$ \\
\hline $\begin{array}{c}\text { C. } \\
\text { bulimoides }\end{array}$ & $\begin{array}{c}\mathrm{R} \\
\text { Sig. }\end{array}$ & $\begin{array}{c}-0.036 \\
\text { NS }\end{array}$ & $\begin{array}{c}0.317 \\
* *\end{array}$ & $\begin{array}{c}0.199 \\
* *\end{array}$ & $\begin{array}{c}0.072 \\
\text { NS }\end{array}$ & $\begin{array}{c}-0.034 \\
\text { NS }\end{array}$ & $\begin{array}{c}0.038 \\
\text { NS }\end{array}$ & $\begin{array}{c}0.094 \\
\text { NS }\end{array}$ & $\begin{array}{c}-0.258 \\
* *\end{array}$ & $\begin{array}{c}0.077 \\
\text { NS }\end{array}$ & $\begin{array}{c}-0.080 \\
\text { NS }\end{array}$ \\
\hline $\begin{array}{c}M . \\
\text { tuberculata }\end{array}$ & $\begin{array}{c}\mathrm{R} \\
\text { Sig. }\end{array}$ & $\begin{array}{c}0.001 \\
\text { NS }\end{array}$ & $\begin{array}{c}0.229 \\
* *\end{array}$ & $\begin{array}{c}-0.001 \\
\text { NS }\end{array}$ & $\begin{array}{c}-0.062 \\
\text { NS }\end{array}$ & $\begin{array}{c}-0.063 \\
\text { NS }\end{array}$ & $\begin{array}{c}-0.057 \\
\text { NS }\end{array}$ & $\begin{array}{c}0.094 \\
\text { NS }\end{array}$ & $\begin{array}{c}0.112 \\
\text { NS }\end{array}$ & $\begin{array}{c}-0.233 \\
* *\end{array}$ & $\begin{array}{c}-0.063 \\
\text { NS }\end{array}$ \\
\hline $\begin{array}{c}T . \\
\text { Niloticus }\end{array}$ & $\begin{array}{c}\mathrm{R} \\
\text { Sig. }\end{array}$ & $\begin{array}{c}-0.024 \\
\text { NS }\end{array}$ & $\begin{array}{c}0.254 \\
* *\end{array}$ & $\begin{array}{c}0.102 \\
\text { NS }\end{array}$ & $\begin{array}{c}-0.003 \\
\text { NS }\end{array}$ & $\begin{array}{c}-0.010 \\
\text { NS }\end{array}$ & $\begin{array}{c}-0.014 \\
\text { NS }\end{array}$ & $\begin{array}{c}0.053 \\
\text { NS }\end{array}$ & $\begin{array}{c}-0.208 \\
* *\end{array}$ & $\begin{array}{c}0.019 \\
\text { NS }\end{array}$ & $\begin{array}{c}-0.110 \\
\text { NS }\end{array}$ \\
\hline $\begin{array}{c}G . \\
\text { senaariensis }\end{array}$ & $\begin{array}{c}\mathrm{R} \\
\text { Sig. }\end{array}$ & $\begin{array}{c}-0.103 \\
\text { NS }\end{array}$ & $\begin{array}{c}-0.114 \\
\text { NS }\end{array}$ & $\begin{array}{c}-0.080 \\
\text { NS }\end{array}$ & $\begin{array}{c}-0.038 \\
\text { NS }\end{array}$ & $\begin{array}{c}-0.058 \\
\text { NS }\end{array}$ & $\begin{array}{c}-0.029 \\
\text { NS }\end{array}$ & $\begin{array}{c}-0.117 \\
\text { NS }\end{array}$ & $\begin{array}{c}-0.059 \\
\text { NS }\end{array}$ & $\begin{array}{c}-0.181 \\
* *\end{array}$ & $\begin{array}{c}0.241 \\
* *\end{array}$ \\
\hline $\begin{array}{c}\text { L. } \\
\text { Natalensis }\end{array}$ & $\begin{array}{c}\mathrm{R} \\
\text { Sig. }\end{array}$ & $\begin{array}{c}-0.076 \\
\text { NS }\end{array}$ & $\begin{array}{c}-0.092 \\
\text { NS }\end{array}$ & $\begin{array}{c}-0.013 \\
\text { NS }\end{array}$ & $\begin{array}{c}-0.080 \\
\text { NS }\end{array}$ & $\begin{array}{c}-0.058 \\
\text { NS }\end{array}$ & $\begin{array}{c}-0.087 \\
\text { NS }\end{array}$ & $\begin{array}{c}-0.077 \\
\text { NS }\end{array}$ & $\begin{array}{c}-0.033 \\
\mathrm{NS}\end{array}$ & $\begin{array}{c}0.103 \\
\text { NS }\end{array}$ & $\begin{array}{c}0.136 \\
*\end{array}$ \\
\hline $\begin{array}{c}\text { S. } \\
\text { Cleopatra }\end{array}$ & $\begin{array}{c}\mathrm{R} \\
\text { Sig. }\end{array}$ & $\begin{array}{c}0.024 \\
\text { NS }\end{array}$ & $\begin{array}{c}-0.104 \\
\text { NS }\end{array}$ & $\begin{array}{c}0.094 \\
\text { NS }\end{array}$ & $\begin{array}{c}-0.033 \\
\text { NS }\end{array}$ & $\begin{array}{c}-0.109 \\
\text { NS }\end{array}$ & $\begin{array}{c}-0.025 \\
\text { NS }\end{array}$ & $\begin{array}{c}-0.155 \\
*\end{array}$ & $\begin{array}{c}-0.141 \\
*\end{array}$ & $\begin{array}{c}0.569 \\
* *\end{array}$ & $\begin{array}{c}0.203 \\
* *\end{array}$ \\
\hline $\begin{array}{c}P . \\
\text { Acuta }\end{array}$ & $\begin{array}{c}\mathrm{R} \\
\text { Sig. }\end{array}$ & $\begin{array}{c}-0.014 \\
\text { NS }\end{array}$ & $\begin{array}{c}-0.092 \\
\text { NS }\end{array}$ & $\begin{array}{c}0.038 \\
\text { NS }\end{array}$ & $\begin{array}{c}-0.022 \\
\text { NS }\end{array}$ & $\begin{array}{c}-0.061 \\
\text { NS }\end{array}$ & $\begin{array}{c}-0.024 \\
\text { NS }\end{array}$ & $\begin{array}{c}-0.168 \\
*\end{array}$ & $\begin{array}{c}-0.084 \\
\text { NS }\end{array}$ & $\begin{array}{c}0.249 \\
* *\end{array}$ & $\begin{array}{c}0.246 \\
* *\end{array}$ \\
\hline $\begin{array}{c}\text { B. } \\
\text { Truncatus }\end{array}$ & $\begin{array}{c}\mathrm{R} \\
\text { Sig. }\end{array}$ & $\begin{array}{c}0.077 \\
\text { NS }\end{array}$ & $\begin{array}{c}0.053 \\
\text { NS }\end{array}$ & $\begin{array}{c}0.103 \\
\mathrm{NS}\end{array}$ & $\begin{array}{c}-0.046 \\
\text { NS }\end{array}$ & $\begin{array}{c}-0.021 \\
\mathrm{NS}\end{array}$ & $\begin{array}{c}-0.029 \\
\text { NS }\end{array}$ & $\begin{array}{c}-0.087 \\
\text { NS }\end{array}$ & $\begin{array}{c}-0.154 \\
*\end{array}$ & $\begin{array}{c}0.174 \\
*\end{array}$ & $\begin{array}{c}-0.051 \\
\text { NS }\end{array}$ \\
\hline $\begin{array}{c}\text { B. } \\
\text { alexandrina }\end{array}$ & $\begin{array}{c}\mathrm{R} \\
\text { Sig. }\end{array}$ & $\begin{array}{c}0.023 \\
\text { NS }\end{array}$ & $\begin{array}{c}-0.034 \\
\text { NS }\end{array}$ & $\begin{array}{c}0.186 \\
* *\end{array}$ & $\begin{array}{c}-0.074 \\
\text { NS }\end{array}$ & $\begin{array}{c}-0.134 \\
*\end{array}$ & $\begin{array}{c}-0.069 \\
\text { NS }\end{array}$ & $\begin{array}{c}-0.210 \\
* *\end{array}$ & $\begin{array}{c}-0.096 \\
\text { NS }\end{array}$ & $\begin{array}{c}0.516 \\
* *\end{array}$ & $\begin{array}{c}0.237 \\
* *\end{array}$ \\
\hline $\begin{array}{c}\text { G. } \\
\text { ehrenbergi }\end{array}$ & $\begin{array}{c}\mathrm{R} \\
\text { Sig. }\end{array}$ & $\begin{array}{c}0.076 \\
\text { NS }\end{array}$ & $\begin{array}{c}0.072 \\
\text { NS }\end{array}$ & $\begin{array}{c}0.048 \\
\text { NS }\end{array}$ & $\begin{array}{c}-0.109 \\
\text { NS }\end{array}$ & $\begin{array}{c}-0.098 \\
\text { NS }\end{array}$ & $\begin{array}{c}-0.113 \\
\text { NS }\end{array}$ & $\begin{array}{c}-0.074 \\
\text { NS }\end{array}$ & $\begin{array}{c}-0.041 \\
\text { NS }\end{array}$ & $\begin{array}{c}0.072 \\
\text { NS }\end{array}$ & $\begin{array}{c}-0.049 \\
\text { NS }\end{array}$ \\
\hline
\end{tabular}

The present results indicated that floating plants(such as Eichornia crassipes and Lemna gibba) were positively correlated with S. cleopatra, P. acuta, B. truncatus and $B$. alexandrina (increased with increasing floating plants) and negatively correlated with B. unicolor, M. tuberculata and G. senaariensis. Also, anchored weeds (such as Ceratophyllum demersum, Myriophyllum spicatum, Potamogeton crispus and Potamogeton pectinatus) were positively correlated with Gabbiella senaariensis, L. natalensis, S. cleopatra, P. acuta and B. alexandrina. Abd El-Malek (1958) reported that water plants are an important factor in the habitat of Bilharziasis snail vectors. El-Gindy (1960) concluded that Bilharzia bearing snails deposit their egg masses on hard broad leaves. Dazo et al. (1966) recorded that Potamogeton crispus and Eichornia crassipes were positively correlated with Bulinus truncatus and Biomphalaria alexandrina. Klumpp \& Chu (1980) indicated that Ceratophyllum demersum was an indicator for the presence of Bulinus rohlfsi, snail vector of Schistosoma haematobium in Volta Lake, Ghana and it is the main factor for determining the duration of the cercarial transmission. Van Schayck (1985) reported that the snails are not directly dependent on aquatic plants but they may prefer a habitat with aquatic vegetation.

However, Utzinger et al. (1997) concluded that the distribution of freshwater snails is a result of more complex interactions of different habitat factors, and Imfidon (1991); Agi (1995) and Agi \& Okwuosa (2001) reported that freshwater snails are known to exhibit high degree of tolerance and adaptation within a reasonable range of physicochemical fluctuation.

\section{CONCLUSIONS}

The results of this study clearly indicate that the densities of the recorded freshwater snails at Qena Governorate underwent changes in numbers during the year 
of investigation. Several environmental factors appear to affect the snail populations, in particular, the presence or absence of the aquatic weeds which maybe cleaned to reduce the populations of snails those act as intermediate hosts for digenean trematods.

\section{REFERENCES}

Abd El-Malek, E. (1958): Factors conditioning the habitat of Bilharziasis intermediate hosts of the family Planorbidae. Bull. Org. mond. Santé. Bull. Wld. Hlth. Org., 18: 785-818.

Aboul-Ela, I. A. \& Beddiny, E. A. M. (1970): On the reproductive processes and the development of Lanistes bolteni (Chemnitz, 1786). Ain Shams Sci. Bull., Cairo, 13: 177-221.

Agi, P. I. (1995): Survey of freshwater snail vectors of Schistosomiasis and study of physicochemical parameters of the water bodies in Ogoni Communities, River State, Nigeria. Act. Hydrobiologica, 21: 31-36.

Agi, P. I. \& Okwuosa, V. N. (2001): Aspects of water quality of freshwater systems harboring snail vectors Schistosome parasites in Jos, Nigeria. Journal of Aquatic Science, 16: 13-17.

Appleton, C. C. (1978): Review of literature on abiotic factors influencing the distribution and life cycles of Bilharziasis intermediate host snails. Malacol. Rev., 11: 1-25.

Barbosa, F. S. \& Barbosa, C. S. (1994): The bioecology of snail vector for Schistosomiasis in Brazil. Cad. Saùde Pùbl., Rio de Janeiro, 10 (2): 200-209.

Boycott, A. E. (1936): The habitat of freshwater molluscs in Britain. J. Anim. Ecol., 5: 116-186.

Brown, D. S. (1994): Freshwater Snails of Africa and their Medical Importance $\left(2^{\text {nd }}\right.$ edn.). Taylor \& Francis, London, 609 pp.

Cañete, R., Yong, M., Sánchez, J., Wong, L. \& Gutiérrez, A. (2004): Population dynamics of intermediate snail hosts of Fasciola hepatica and some environmental factors in San Juan Martinez Municipality, Cuba. Mem. Inst. Oswaldo Cruz, Rio de Janeiro, 99 (3): 257-262.

Dazo, B. C., Hairston, N. G. \& Dawood, I. K. (1966): The ecology of Bulinus truncatus and Biomphalaria alexandrina and its implications for the control of Bilharziasis in the Egypt- 49 Project Area. Bull. Org. mond. Santé Bull. Wld Hlth Org., 35: 339-356.

Demian, E. S. \& Kamel, E. G. (1972): Growth and population dynamics of Bulinus truncatus under semi-field conditions in Egypt. Proceeding of the Egyptian academy of Science, 25: 37-60.

Diab, M. R. M. (1993): Biological studies on Trematode larvae and freshwater snails. M. Sc. Thesis, Vet. Med. Fac., Alexandria Univ., 155 pp.

Dussart, G. B. J. (1976): The ecology of freshwater molluscs in North West England in relation to water chemistry. Journal of Molluscan Studies, 42: 181-198.

Dussart, G. B. J. (1979): Life cycles and distribution of the aquatic gastropod mollusc Bithynia tentaculata (L.) Gyraulus albus (Müller), Planorbis planorbis (L.) and Lymnaea peregra (Müller) in relation to water chemistry. Hydrobiologia, 67: 233-239.

El-Gindy, H. I. (1960): On the ecology of snail intermediate hosts of Schistosoma and Fasciola. Ph. D. Thesis, Faculty of Science, Cairo University. 
El-Kady, G. A., Shoukry, A., Reda, L. A. \& El-Badri, Y. S. (2000): Survey and population dynamics of freshwater snails in newly settled areas of the Sinai Peninsula. Egyptian Journal of Biology, (2): 42-48.

El-Khayat, H. M., Ismail, N. M., Mahmoud, K. M., Ragb, F. M., El-Said, K. M., Mostafa, B. B., El-Deeb, F. A. \& Tantawy, A. A. (2011): Evaluation of some chemical parameters as potential determinants of freshwater snails with special reference to medically important snails in Egypt. World Acad. Sci., Eng. Techn., 59: 1313-1326.

Heikal, F. A. and El-Sokkary, M. Y. (1986): Survey on the different types of the snails in Beheira Governorate. Alexandria Journal of Veterinary Science, 2(2): 457-472.

Ibrahim, A. M., Bishai, H. M. \& Kalil, M. T. (1999): Freshwater Molluscs of Egypt. Egyptian Environmental Affairs Agency (EEAA), National Biodiversity Unit, No. $10,145 \mathrm{pp}$.

Imafidon, E. U. (1991): Ecological studies of freshwater snails in Ibadan, Nigeria. Nigerian Journal of Parasitology, 12: 59-63.

Imevbore, A. M. A., Ofoezie, I. E. \& Obot, E. A. (1988): Vector-borne disease problems of small scale water recourses development project in Kano State. 1. Snail vector of Schistosomiasis, Afrancet, Ibadan, 1: 17-23.

Karimi, G. R. (2003): Epidemiological studies on Ornithobilharzia turkestanicum in sheep and its snail in Shadegan area and evaluation of serological tests for diagnosis of infection. Ph. D. Thesis, Ahwaz University, Iran (in Persian).

Karimi, G. R., Derakhshanfar, M. \& Paykari, H. (2004): Population density, trematodal infection and ecology of Lymnaea snails in Shadegan, Iran. Arch. Razi Inc., 58: 125-129.

Kazibwe, F., Makanga, B., Rubaire-Akiiki, C., Ouma, J., Kariuki, C., Kabatereine, N. B., Booth, M., Vennervald, B. J., Sturrock, R. F. \& Stothard, J. R. (2006): Ecology of Biomphalaria (Gastropoda: Planorbidae) in Lake Albert, Western Uganda: snail distribution, infection with schistosomes and temporal associations with environmental dynamics. Hydrobiologia, 568: 433-444.

Kloos, H., de Souza, C., Gazzinelli, A., Filho, B. S. S., de Costa Temba, P., Bethony, J., Page, K., Grzywacz, C., Lewis, F., Minchella, D., Loverde, P. \& Oliveira, R. C. (2001): The distribution of Biomphalaria spp. In different habitats in relation to physical, biological, water contact and cognitive factors in a rural area in Minas Gerais, Brazil. Mem. Inst. Oswaldo Cruz, Rio de Janeiro, 96: 57-66.

Klumpp, R. K. \& Chu, K. Y. (1977): Ecological studies of Bulinus rohlfsi, the intermediate host of Schistosoma haematobium in the Volta Lake. Bull. WHO, 55: 715-730.

Klumpp, R. K. \& Chu, K. Y. (1980): Importance of the aquatic weed Ceratophyllum to transmission of Schistosoma haematobium in the Volta Lake, Ghana. Bulletin of the World Health Organization, 58 (5): 791-798.

Lacoursière, E., Vaillancourt, G. \& Couture, R. (1975): Relation entre les plantes aquatiques et les Gastéropodes (Mollusca: Gastropoda) dans la région de la centrale nucléaire de Gentilly I (Quèbec). Can. J. Zool. 53: 1868-1874.

Macan, T. T. (1950): Ecology of freshwater in the English Lake District. J. anim. Ecol., 19: 124-146.

Maqbool, A., Hayat, C. S., Tanveer, A., Salahuddin, M. \& Arfan, A. (2003): Prevalence and ecology of Lymnaea snails in Punjub. Iranian Journal of Veterinary Research, 8: 192-195. 
Mckillop, W. B. (1985): Distribution of aquatic gastropods across the Ordovician dolomite- Precambrian granite contact in south eastern Manitoba, Canada. Can. J. Zool., 63: 278-288.

Mckillop, W. B. \& Harrison, A. D. (1972): Distribution of aquatic gastropods across an interface between the Canadian Shield and limestone formation. Can. J. Zool., 50: 1433-1445.

Mostafa, O. M. S. (2009). Effect of salinity and drought on the survival of Biomphalaria arabica, the intermediate host of Schistosoma mansoni in Saudi Arabia. Egyptian Academic Journal of Biological Science, 1 (1): 1-6.

Ofoezie, I. E. (1999): Distribution of freshwater snails in the man-made Oyan Reservoir, Ogun State, Nigeria. Hydrobiologia, 416: 181-191.

Owojori, O. J., Asaolu, S. O. \& Ofoezie, I. E. (2006): Ecology of freshwater snails in Opa Reservoir and research from ponds at Obafemi Awolowo University IleIfe, Nigeria. Journal of Applied Sciences, 6 (15): 3004-3015.

Pointier, J. P., Théron, A. \& Borel, G. (1993): Ecology of the introduced snail Melanoides tuberculata (Gastropoda: Thiaridae) in relation to Biomphalaria glabrata in the marshy forest zone of Guadeloupe, French West Indies. J. Moll. Stud., 59: 421-428.

Ramzy, R. R. (2009): Biological and ecological studies on land snails at Assiut, Egypt. M. Sc. Thesis, Zool. Dep., Sci. Fac., Assiut Univ., 190 pp.

Strzelec, M. \& Królczyk, A. (2004): Factors affecting snail (Gastropoda) community structure in the upper course of the Warta river (Poland). Biologia, Bratislava, 59(2): 159-163.

Subba-Rao, N. V. (1993): Freshwater Molluscs of India. In: Roa K.S. (Ed.). Recent Advances in Freshwater Biology. New Delhi. Animal Publication, 2: 187202.

Supian, Z. \& Ikhwanuddin, A. M. (2002): Population dynamics of freshwater molluscs (Gastropod: Melanoides tuberculata) in Crocker Range Park, Sabah. ASEAN Review of Biodiversity and Environmental Conservation (ARBEC).

Utzinger, J., Mayombana, C., Mez, K. \& Tanner, M. (1997): evaluation of chemical and physical morphological factors as potential determinants of Biomphalaria pfefferi (Krauss, 1848) distribution. Mem. Inst Oswaldo Cruz, Rio de Janeiro, 92(3): 323-328.

Van-Schayck, IR. C. P. (1985): Laboratory studies on the relation between aquatic vegetation and the presence of two Bilharzia-bearing snail species. J. Aquat. Plant Manage, 23: 87-91.

Vermani, O. P. \& Narula, A. K. (1995): Applied Chemistry (Theory and Practical). $2^{\text {nd }}$ ed., New age international (P) limited, Publishers, New Delhi.

Vincent, B., Lafontaine, N. \& Caron, P. (1982): Facteurs influencant la structure des groupements de macroinvertébrés benthiques et phytophiles dans la zone littorale du Saint-Laurent (Québec). Hydrobiologia, 97: 63-73.

Williams, N. V. (1970): Studies on aquatic pulmonate snails in Central Africa. I: Field distribution in relation to water chemistry. Malacologia, 10: 153-164.

Zaki, H. Y. M. (2008): Survey on snail populations at Abis district, Egypt. M. Sc. Thesis, Dep. of Parasitology, Faculty of Vet. Med., Alexandria Uni., 94 pp. 


\section{ARABIC SUMMARY}

ديناميكية عثائر قواقع المياه العذبة (رخويات: بطنية القدم) في محافظة قنا، صعيد مصر

محمد أحمد حسين1، أحمد حامد عبيد اللها، أمال أحمد محمود²، هبه محمد فنجري2

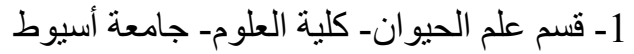

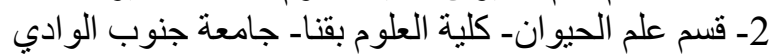

تم إجر اء در اسة بيئية علي التغير ات الثهرية و الموسمية التي طر أت علي كثافة قو اقع المياه العذبة في

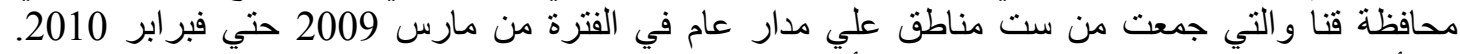

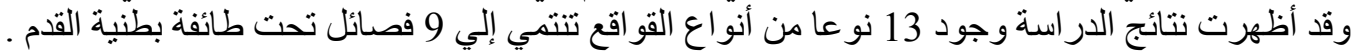

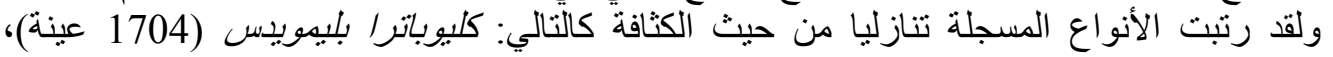

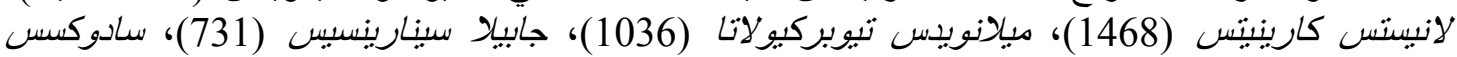

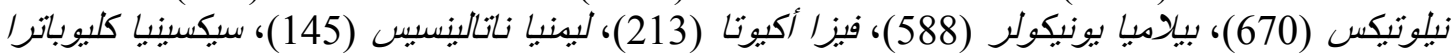

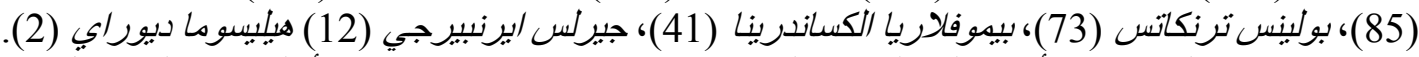

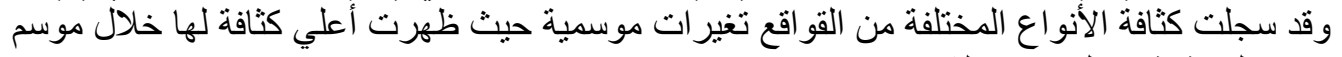
الخريف بينما اقل كثافة خلال موسم الثنتاء.

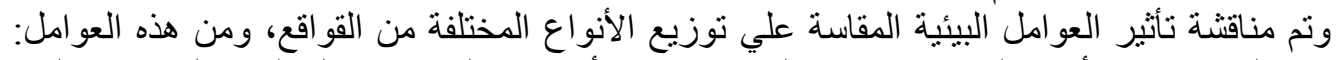

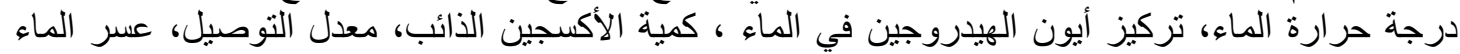

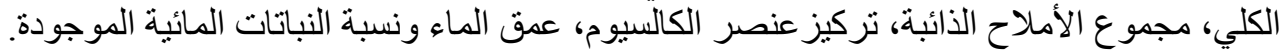

